\title{
Erratum
}

\section{Erratum to the article: "Sustainable port-hinterland intermodal development: Opportunities and challenges for China and India"}

\author{
Yimiao $\mathrm{Gu}^{1 *}$, Huishan $\mathrm{Loh}^{2}$ and Wei Yim Yap \\ ${ }^{1}$ Department of Electronic Business/Institute of Digital Business \& Intelligent Logistics, South China University of \\ Technology, Guangzhou, China \\ ${ }^{2}$ Logistics and Supply Chain Management Programme, School of Business, Singapore University of Social Sciences \\ Singapore
}

Erratum to

doi: 10.24294/jipd.v4i2.1227

Published in Vol 4, No 2 (2020) by EnPress Publisher.

The original article can be found at https://systems.enpress-publisher.com/index.php/jipd/article/view/1227

The authors would like to add the following acknowledgements to Gu Y, Loh HS and Yap WY (2020).

Acknowledgements This project received funding support the Youth Foundation of the Humanities and Social Sciences Research of the Ministry of Education of China [grant no.17YJCGJW002] and the Development of Philosophy and Social Science of Guangzhou city [grant no. 2018GZYB24].

\section{Reference}

Gu Y, Loh HS and Yap WY (2020). Sustainable port-hinterland intermodal development: Opportunities and challenges for China and India. Journal of Infrastructure, Policy and Development, 4(2): 228-248. doi: 10.24294/jipd. v4i2.1227.
Available online: May 12, 2021

*CORRESPONDING AUTHOR Yimiao Gu, Department of Electronic Business/Institute of Digital Business

\& Intelligent Logistics, South China University of Technology, Guangzhou, China; guymcheers@scut.edu.cn

CITATION

Gu Y, Loh HS and Yap WY (2021).

Erratum to the article: "Sustainable port-hinterland intermodal development: Opportunities and challenges for China and India". Journal of Infrastructure, Policy and Development, 5(1): 1249 . doi: 10.24294/jipd.v5i1.1249 COPYRIGHT

Copyright (C) 2021 by author(s) and EnPress Publisher LLC. This work is licensed under the Creative Commons Attribution-NonCommercial 4.0 International License (CC BY-NC 4.0). http://creativecommons.org/licenses/ by/4.0/ 